Abstracta Iranica Iranica

Revue bibliographique pour le domaine irano-aryen

Volume 24 | 2003

Comptes rendus des publications de 2001

\title{
" The Conversion of Tegüder Ilkhan to Islam ». JSAI, 25 (2001), pp. 15-43.
}

\section{Denise Aigle}

\section{(2) OpenEdition}

1 Journals

Édition électronique

URL : http://journals.openedition.org/abstractairanica/34377

DOI : 10.4000/abstractairanica.34377

ISSN : 1961-960X

\section{Éditeur :}

CNRS (UMR 7528 Mondes iraniens et indiens), Éditions de l'IFRI

\section{Édition imprimée}

Date de publication : 15 mai 2003

ISSN : 0240-8910

\section{Référence électronique}

Denise Aigle, « «The Conversion of Tegüder Ilkhan to Islam ». JSAI, 25 (2001), pp. 15-43. », Abstracta Iranica [En ligne], Volume 24 | 2003, document 101, mis en ligne le 05 janvier 2010, consulté le 25 septembre 2020. URL : http://journals.openedition.org/abstractairanica/34377 ; DOI : https://doi.org/ 10.4000/abstractairanica.34377

Ce document a été généré automatiquement le 25 septembre 2020.

Tous droits réservés 


\title{
«The Conversion of Tegüder Ilkhan to Islam ». JSAI, 25 (2001), pp. 15-43.
}

\author{
Denise Aigle
}

1 S'appuyant sur un large éventail de sources islamiques, en arabe et en persan et de sources chrétiennes, en syriaque et en arménien, l'objectif de l'auteur est, ici, d'examiner les conséquences politiques de la conversion de Tegüder à l'islam. Premier souverain mongol d'Iran musulman, Tegüder fut aussi le premier à être déposé par d'autres Mongols.

2 Tegüder était musulman depuis longtemps lorsqu'il accéda au pouvoir mais il fit de l'islam un sujet public en envoyant, notamment, une ambassade aux Mamelouks afin de faire cesser l'état de guerre entre les deux puissances. Adel Allouche («Tegüder's Ultimatum to Qalawun ", International Journal of Middle East Studies 22, 4 (1990), pp. 439-446) a montré le caractère belliqueux de la lettre envoyée au sultan à Qalāwūn ; elle est écrite en conformité avec le modèle traditionnel des lettres que les Mongols envoyaient aux souverains qu'ils souhaitaient soumettre. Cette initiative diplomatique peut s'interpréter comme un acte de portée symbolique.

L'auteur analyse les récits, très contradictoires, sur la première vie religieuse de Tegüder et sa conversion à l'islam. Il ne fait pas de doute que Tegüder fut attiré vers l'islam pendant sa jeunesse, au contact de l'islam soufi (voir du même auteur, "Sufis and Shamans: some Remarks on the Islamization of the Mongols in the Ilkhanate ", JESHO 42,1 (1999), pp. 27-46, c.r. dans Abs. Ir. 23, (2000), n² 209). Les sources mamelouks mentionnent dans son entourage le nom de plusieurs cheikhs soufis. Selon al-Dahabī, ce serait au contact des Aḥmadiyya, les disciples de Aḥmad al-Rifā'ī, qu'il aurait été introduit à l'islam. Le récit d'al-Dahabī vise, bien entendu, à disqualifier l'islam de Tegüder en le présentant au contact de soufis peu orthodoxes dans leurs pratiques. Un autre cheikh aurait joué un rôle important dans la formation spirituelle de Tegüder, Kamīl al-Dīn 'Abd al-Raḥmān, un personnage sans connaissance religieuse particulière mais qui exerça sur Tegüder une forte influence charismatique. Après l'intronisation de l'Ilkhan, il continua à être son conseiller spirituel et devint très influent dans les affaires religieuses et les affaires de l'État. Rašīd al-Dīn mentionne une autre figure 
importante dans l'entourage de Tegüder : Īshān Mengli, un disciple de Bābā Ya 'qūb de Arrān, qui était associé à la Qalandariyya ; la tente de Mengli était proche de l'ordo de l'llkhan. En contact pendant sa jeunesse avec les représentants d'un soufisme populaire, Tegüder le resta après son accession au pouvoir.

4 Afin de se présenter comme un souverain musulman orthodoxe, Tegüder mit en œuvre une politique d'islamisation. Il chercha à renforcer le caractère islamique de la société par des actions spectaculaires comme la conversion de lieux de culte non musulmans en mosquées et en ordonnant la construction d'édifices religieux.

5 La politique d'islamisation pratiquée par Tegüder fut-elle la raison de sa déposition? L'auteur ne souscrit pas aux anciennes thèses qui ont vu dans cette déposition un mobile religieux mais il pense, à la suite de Jean Aubin, que c'est le manque de compétence de l'Ilkhan qui fut la cause de sa chute. L'historien mamelouk, Ibn alDawādārī, ne décrit-il pas Tegüder comme un souverain ayant peu de sens politique?

INDEX

Thèmes : 4.1. Histoire médiévale

\section{AUTEURS}

DENISE AIGLE

IFEAD - Damas 